\title{
SEXUAL SELECTION AND SOCIAL HIERARCHY IN FISHES
}

\author{
Eliane Gonçalves-de-Freitas*, André Luis da Silva Castro, Thaís Billalba Carvalho \& Francine \\ Zocoler de Mendonça \\ Universidade Estadual Paulista - UNESP - Laboratory of Animal Behavior, Department of Zoology and Botany, IBILCE, São José do Rio Pre- \\ to, SP, Brazil. UNESP Aquaculture Center (CAUNESP) and Research Center for Animal Welfare (RECAW-CNPq). - R. Cristóvão Colombo, 2265, \\ CEP 15054-000, São José do Rio Preto, SP, Brasil. \\ *E-mail: elianeg@ibilce.unesp.br
}

\begin{abstract}
Sexual selection is a crucial element to understand behavioral evolution. Teleost fish have been considered as good models for research on sexual selection in the last decades due to their variety of sexual behavior. Female fish can choose males based on body and behavioral traits, such as body size, body color, ornaments, territorial quality, nest size and courtship behavior. Choices are based upon several types of sensorial inputs, such as visual, chemical, sonorous and electrical signals. Intrasexual selection also acts on females because they can mate with a dominant individual in male-male competitions. For both approaches, there is an expectation regarding the benefits of sexual selection by means of female choice. However, in several cases females do not choose the dominant male. In this mini-review, we present and discuss both intersexual and intrasexual mechanisms of sexual selection in fish and point out that females do not always choose a male for mating.

Key-words: Courtship, communication, morphological traits, Teleost, reproductive behavior.

\section{RESUMO}

SELEÇÃO SEXUAL E HIERARQUIA SOCIAL EM PEIXES. A seleção sexual é um assunto de amplo interesse para entendimento da evolução comportamental. Os Teleósteos têm sido considerados bons modelos para pesquisas em seleção sexual nas últimas décadas devido à sua variedade de comportamentos sexuais. As fêmeas podem escolher os machos com base em características corporais e comportamentais, como tamanho corporal, coloração, ornamentos, qualidade do território, tamanho do ninho e corte. Tal escolha ocorre por meio de várias informações sensoriais, como sinais visuais, químicos, sonoros e elétricos. A seleção intrasexual também atua sobre as fêmeas porque elas podem selecionar um dominante para acasalar em situação de competição entre machos. Nas duas abordagens, há uma expectativa relacionada aos benefícios oriundos da seleção sexual por meio da escolha da fêmea. No entanto, em vários casos, a fêmea não escolhe o macho dominante. Nesta mini revisão, nós apresentamos e discutimos os mecanismos da seleção inter e intra-sexual em peixes e destacamos que as fêmeas nem sempre escolhem o macho com quem acasalar.
\end{abstract}

Palavras-chave: Corte, características morfológicas, teleósteos, comportamento reprodutivo.

\section{RESUMEN}

SELECCIÓN SEXUAL Y JERARQUIA SOCIAL EN PECES. La selección sexual es un asunto de amplio interés para el entendimiento de la evolución del comportamiento. En las últimas décadas los peces Teleósteos han sido considerados buenos modelos para investigaciones sobre selección sexual debida su amplia variedad de comportamientos sexuales. Las hembras pueden escoger a los machos basándose en características corporales y comportamientos, tales como tamaño corporal, coloración, ornamentos, calidad del territorio, tamaño del nido y cortejo. Tal escogencia ocurre a través de diversas informaciones sensoriales, como señales visuales, químicas, sonoras y eléctricas. La selección intra-sexual también actúa sobre las hembras porque ellas pueden seleccionar un macho dominante para aparearse en una situación de competencia entre machos. En ambos casos, hay una expectativa relacionada a los beneficios naturales de la selección sexual por medio de la escogencia de la hembra. Sin embargo, en algunos casos, la hembra no escoge el macho dominante. En esta mini-revisión, presentamos y discutimos los mecanismos de la selección inter e intra-sexual en peces y destacamos que las hembras no siempre escogen el macho con el que se van a aparear.

Palabras clave: Cortejo, características morfológicas, teleósteos, comportamiento reproductivo. 


\section{INTRODUCTION}

Why do some males or females mate while other mature individuals do not? Why do some individuals obtain a higher reproductive success? Such differences in reproductive ability result from two important mechanisms: male-male competition and female choice (Andersson 1994). Both mechanisms are part of Darwin's theory of sexual selection named, respectively, intrasexual and intersexual selection (Andersson \& Iwasa 1996). According to this theory, reproductive decisions may maximize individual fitness. Although males and females contribute equally to the brood's genetic pool, the energetic investment of the female is higher than that of the male (Andersson \& Simmons 2006). This explains why mate choice is less pronounced in males than females. In fact, such an explanation was given by Trivers' Parental Investment Theory, which predicts that the sex that invests more heavily in the offspring, at the expense of potential future offspring, should face the least competition (Ahnesjö et al. 2008).

Fitness can be enhanced by direct benefits (e.g., by enhancing brood size); or indirect fitness (e.g., by enhancing the lifespan and, indirectly, the reproductive success) (Barbosa \& Magurran 2006). Because females spend more energy during reproduction, they should select good mates, or good males in terms of genetic quality for brood survival, in order to enhance fitness (Andersson 1994). By choosing mates, female can acquire direct benefits, such as brood protection, higher fertilization rate and resources; or indirect benefits, such as higher survival rate for broods and parasite resistance (Berglund et al. 1996, Barbosa \& Magurran 2006, Lailvaux \& Irschick 2006, Candolin \& Wong 2008).

One important environmental trait related to variations in choice is the operational sex ratio (OSR) (Emlen \& Oring 1977). The OSR is the ratio of the number of males to females, in a given population, that are ready to mate at a given time and place (Emlen \& Origin 1977, Kvarnemo \& Ahnesjö 1996). Thus, when OSR is biased, sexual selection will act more strongly on the more abundant sex (Emlen \& Oring 1977). Thus, literature provides us with several hypotheses to explain variability in sexual strategies for mate selection (e.g., Clutton-Brock 2007, Ahnesjö et al. 2008). In fishes, mate choice can be modified by operational sex ratio, nest quality and other environmental conditions that cause a sex reversal role (e.g., Andersson \& Iwasa 1996, Gonçalves et al. 2002a, Forsgren et al. 2004, Barlow \& Lee 2005). In the cichlid Astatotilapia flaviijosephi, males choose larger females because body size is positively associated with number of eggs (Werner \& Lotem 2003). Thus, males also acquire reproductive benefits by choosing larger and heavier females (Kraak \& Bakker 1998, Dosen \& Montgomerie 2004, Herdman et al. 2004). Moreover, there are some species with sex role reversal, such as the pipefish, Syngnathus typhle (Berglund \& Rosenqvist 2003) and bleniid fish, Salaria pavo (Gonçalves et al. 2002a, 2002b), in which females court males. In some circumstances, the number of males ready to reproduce can be reduced in the population, consequently shifting the OSR towards females which, in turn, increases female-female competition, courtship and aggression (Shibata \& Kohda 2006).

When OSR is biased toward males, enhanced competition for females will result (Andersson \& Iwasa 1996). Considering intersexual selection, females can choose males based on body and behavioural traits, or they can mate with a winner in male-male competitions. In social fishes, such as cichlids, theory predicts that females should prefer larger and also more aggressive males that could better hold territories and defend offspring against predators (Barlow 1998). In this mini-review, we discuss the main mechanisms of sexual selection of fishes and also discuss why females do not always choose males. This suggests female choice is sometimes obscured by male social position.

\section{THE WAY TO CHOOSE - COMMUNICATION}

Selection of a mate depends on signals displayed by males and females. Such signals are displayed by different sensory channels, depending on the environment and the sensorial input-output adaptations. The studies related to sex communication are essentially those linked to visual signs, probably because these are the first ones to attract our attention. In fact, vision is only one input channel for fish communication and not the most important one (Giaquinto \& Volpato 1997, Rosenthal \& Lobel 2006). Moreover, the opposite sex usually evaluates 
more than one sensorial cue coordinated in a set of sensorial information. Visual communication can be useful to evaluate body colour, body size, nest, territory quality, and courtship movements. In the three-spined stickleback, for example, the more red and bright the male's belly, the stronger stimulus to attract females (Bakker \& Milinski 1993). Moreover, Poecilidae females prefer the intensity of orange in the male body. Iridescent spots in the male's body are attractive to females and enhance the male mating success (Kodric-Brown 1993).

Courtship is one of the most potent visual signals to the opposite sex. In the sex role reversed fish $S$. pavo, female courtship behaviour is elicited exclusively by male visual features (Gonçalves et al. 2002b). In Nile tilapia, Oreochromis niloticus, spawning occurs even when males are separated from the female by a transparent glass, without chemical or physical contact (Castro et al. 2009 in press). In this study, male visual contact with the female enhanced the courtship rate and also the gonadossomatic index, thus reinforcing the importance of visual stimulus to courtship and also to control reproduction in fish (Castro et al. 2009 in press).

Chemicals are involved in fish behaviour in several ways (e.g., Giaquinto \& Volpato 1997, 2005, Gonçalves-de-Freitas et al. 2008), and reproduction is obviously one of them (e.g. Volpato et al. 2006, Barata et al. 2008, Serrano et al. 2008). In fact, Almeida et al. (2005) showed that male Oreochromis mossambicus urinates in the presence of females. Since urine is a way of communication in reproductive behaviour, it is assumed to be used during mate choice. Fisher \& Rosenthal (2006) found that female swordtail fish, Xiphophorus birchmanni, prefer the chemical cues from well-fed males than from food-deprived males. Moreover, the authors found no consistent female discrimination regarding the nutritional state of other females, showing that the preference is sex-specific. In addition, McLennan \& Ryan (2008) found that the olfactory cues in other Xiphophorus spp. transmit complex information about species identification and sexual status (sneaker males and courting males).

Sound production is another way of signalling reproductive traits in fishes. Although studies on fish sound production are incipient, a few studies are devoted to reproductive traits and sexual selection. Recent studies on the African cichlids Pseudotropheus spp. show that male sound is emitted during the courtship displays, and the sound rate increases significantly with courtship (Amorim et al. 2004, 2008). Additionally, Phillips \& Johnston (2008) also demonstrated the role of sound production in agonistic and courtship interactions in the fish Cyprinella galactura.

Electric cues are restricted to electric fishes and also have a role in sexual communication. The function of electric pulses in courtship behaviour has been studied in gymnotid Sternopygus macrurus (Hopkins 1974) and Apteronotus leptorhynchus (Triefenbach \& Zakon 2003). African mormyrid species also show specific self-generated electric pulses and electroreceptive abilities for orientation, communication, territorial interactions and for courtship (Terleph \& Moller 2003, Wong \& Hopkins 2007, Baier \& Kramer 2007). In the mormyrid Marcosenius pongolensis, the male's reproductive success is enhanced by longer and more attractive electric organ discharges (Machnik \& Kramer 2008).

\section{WHAT DO FEMALES CHOOSE}

Females can choose male phenotypic traits, including courtship displays, nuptial coloration, ornaments, pheromones, body size, and territory quality (Andersson 1994, Barbosa \& Magurran 2006, Fagundes et al. 2007, Ahnesjö et al. 2008, Labonne et al. 2009). All these traits are sources of information about male quality that attract females and that can enhance female reproductive success. Table I summarizes some of these traits in several species of fish. Indirect benefits are provided by choosing "good genes" (Andersson 1994) and "sexy sons" (Weatherhead \& Robertson 1979). In both mechanisms, the male traits are inherited by broods, and enhance either the chance of survival (good genes theory) or the chance to reproduce (sexy sons theory) (Barbosa \& Magurran 2006). In the three-spined stickleback (Gasterosteus aculeatus), for example, mate choice is positively correlated to female reproductive success (Kraak et al. 1999), thus supporting the predictions of sexual selection.

Female choice implies several types of benefits. In species with parental care, females may enhance reproductive success by choosing good fathers that can help to improve egg hatching and brood survival 
(Forsgren 1997, Östlund \& Ahnesjö 1998, Takahashi \& Kohda 2004, Wong 2004). Female brown trout (Salmo trutta) choose less aggressive males, thus avoiding losses due to male attacks (Petersson et al. 1999). In G. aculeatus, the most colourful males have broods more resistant to parasites (Barber et al. 2001), which is in accordance to Hamilton's \& Zuck's hypothesis (Krebs \& Davies 1993). Moreover, male G. aculeatus build nests with algae and females prefer sticks and spangles nests (Östlund-Nilsson \& Holmlund 2003). By ornamenting their nests, males show their paternal qualities (Östlund-Nilsson \& Holmlund 2003). In fact, as illustrated by this species, female can choose several male signals that, together, give more complete information about male quality (Kunzler \& Bakker 2001, Hankison \& Morris 2003). Female choice, however, can be affected by environmental conditions. Increased predation risk, for instance, can change male body colour preference in guppies (Godin \& Briggs 1996, Locatello et al. 2006). Female choice is also affected by food availability, competition, habitat quality and other factors that affect fertility, growing and survival of a population (Charnov 2001).

\section{MALE DOMINANCE AND FEMALE CHOICE}

Although female choice can be based on several male traits, another mechanism involved in sexual selection is mating through resource competition. Thus, intrasexual selection, usually more strong among males, will select for fighting ability (Halliday 1994). Because male-male competition is an honest signal, females can easily detect male abilities (Sargent et al. 1998, Candolin 2000), and choose dominant males.

The most common type of competition among fish involves aggressive interactions, and a hierarchical rank can arise. Dominance hierarchy is part of social behaviour where the winner in a contest is the dominant, and the loser, the subordinate (Ridley 1995). Dominants have priority access to resources such as food, shelter, nest sites and mates (Huntingford \& Turner 1987, Ridley 1995). Moreover, dominants usually grow faster than subordinates, as seen for example in the Nile tilapia, O. niloticus (Volpato \& Fernandes 1994) and Haplochromis burtoni (Hofmann et al. 1999). As a result, dominant males are preferred by females because of the resources needed or because of their good genes (Qvarnström \& Forsgren 1998).

Table I. Examples of male's traits chosen by females in several fish species.

\begin{tabular}{|c|c|c|}
\hline Species & Traits of preferred males & References \\
\hline Poecilia mexicana & Larger dorsal fins. & Jordan et al. (2006) \\
\hline Xiphophorus birchmanni & Well-fed mates (chemical cues). & Fisher \& Rosenthal (2006) \\
\hline Rhinogobius brunneus & $\begin{array}{l}\text { Males that courted in the faster water } \\
\text { streams. }\end{array}$ & Takahashi \& Kohda (2004) \\
\hline Pseudotropheus zebra & $\begin{array}{l}\text { Longer pelvic fins and larger number of } \\
\text { eggspots in anal fins. }\end{array}$ & Couldridge \& Alexander (2001) \\
\hline Astatotilapia burtoni & $\begin{array}{l}\text { Territorial males over non-territorial males; } \\
\text { more active territorial males. }\end{array}$ & Clement et al. (2004) \\
\hline Pomatoschistus minutus & Courtship intensity . & Forsgren (1997) \\
\hline Poecilia reticulata & $\begin{array}{l}\text { High display rates, more complex } \\
\text { ornamentation, more orange ornamentation } \\
\text { and prolonged swimming performance. }\end{array}$ & Nicoletto (1993) \\
\hline Spinachia spinachia & More frequent body shakes during courtship. & Östlund \& Ahnesjö (1998) \\
\hline Pterapogon Kauderni & Larger male. & Kolm (2001) \\
\hline Xiphophorus helleri & $\begin{array}{l}\text { Partial swords containing complete black } \\
\text { stripes coloration, Longer swords. }\end{array}$ & Trainor \& Basolo (2006) \\
\hline Salmo trutta & Larger adipose fin. & Petersson et al. (1999) \\
\hline Oreochromis mossambicus & Larger body size and larger spawning pit. & Nelson (1995) \\
\hline Rhodeus sericeus & $\begin{array}{l}\text { Larger body size and more vigorously } \\
\text { courting. }\end{array}$ & Reichard et al. (2005) \\
\hline Pseudomugil signifer & $\begin{array}{l}\text { Greater proportion of time engaged in } \\
\text { courtship. }\end{array}$ & Wong (2004) \\
\hline Gasterosteus aculeatus & $\begin{array}{l}\text { Males with decorated nest (colorful sticks and } \\
\text { spangles). }\end{array}$ & Östlund-Nilsson \& Holmlund (2003) \\
\hline
\end{tabular}


In fact, many studies show female choice is based on social rank (Bisazza \& Marin 1991, Kodric-Brown 1992, Candolin 1999, Berglund \& Rosenqvist 2001) or in traits associated to dominance, such as nest size (McKaye et al. 1990, Stauffer et al. 2005, Mendonça \& Gonçalves-de-Freitas 2008), body size (Santangelo 2005, Gonçalves et al. 2002a, Labonne et al. 2009), territory quality (Halliday 1994, Dijkstra et al. 2008), body colour (Kraak \& Bakker 1998, Cubillos \& Guderley 2000, Morris et al. 2007), courtship frequency (Forsgren 1997, Cubillos \& Guderley 2000) and aggressive level (Gozlan et al. 2003). Several studies have demonstrated the advantages of being dominant in terms of reproductive success. However, this might be the male's view, as we discuss further.

\section{DO FEMALES FISH REALLY PREFER DOMINANT MALES?}

Social dominance requires large investment from males, which in turn could be compensated by enhancing their reproductive success. However, recent studies show that in some fish species females rarely choose the dominant male for mating (Qvarnström \& Forsgren 1998, Östlund-Nilsson \& Nilsson 2000, Candolin \& Wong 2008). In Pseudomugil signifer, for example, females prefer males that exhibit more courtship movements and also provide more care to the brood, instead of dominant males (Wong 2004). In the poecilid, Limia perugia, fingerprint analysis showed that dominant males had a mating success of $100 \%$ in small mating groups, but it dropped to $0 \%$ in larger groups (Schartl et al. 1993). Thus, it seems that female choice depends on a set of requirements instead of social status alone. On the other hand, malemale competition can reduce the chances for female choice. According to Reichard et al. (2005), females of Rhodeus sericeus, physically separated from males, choose those males that exhibit more courtship. However, when interacting with them, spawning does not occur with the chosen male (when the chosen one is subordinate) because dominant males do not allow subordinates to approach females (Reichard et al. 2005). In another study with G. aculeatus, females were allowed to interact and mate with each male, while physical interactions between the males were prevented by leashing them to opposite corners of the aquarium. In such a situation, females did not prefer dominant males; but when the males could freely interact with each other, females chose the dominants (Östlund-Nilsson \& Nilsson 2000). In this case the dominant male prevented the female from interacting with the subordinate male (Östlund-Nilsson \& Nilsson 2000), a result that reinforces the view that dominants are not always the female's choice, but can be a forceful result of male-male competition. According to Kangas \& Lindstrom (2001), female Pomastoschistus minutus do not choose dominant males, and neither male aggressive interaction limit a female's possibilities to spawn with a non-dominant male. In the Nile tilapia, nest building is an element for mate choice (Mendonça \& Gonçalves-de-Freitas 2008). However, nests are built by dominant males, and provide reproductive advantages (Gonçalvesde-Freitas \& Nishida 1998). Although the Nile tilapia is able to reproduce in the absence of a nest, the dominant still reproduces first (Mendonça \& Gonçalves-de-Freitas 2008). However, females that view males (separated by glass with no other cue involved), do not choose the dominant males (Castro 2008). In this species, the presence of sneaking behaviour (Gonçalves-de-Freitas \& Nishida, 1998) could indicate that females do not prefer dominants, as suggested by Candolin \& Wong (2008).

In some poecilids, male-male competition is the extreme threshold for accessing females. Subordinate males Poecilia reticulata have their sexual behavior suppressed (Bruce \& White 1995). In Xiphophorus species, maturation is socially inhibited (Borowsky 1987): dominant's agonistic interactions inhibit subordinate's gonads, thus circumventing female choice. Hence, Birkhead \& Møller (1993) suggested that females can be, in some cases, passive subjects relative to decisions about mating. In fact, dominant males that monopolize resources needed by females also monopolize the females themselves, and prevent other males from approaching females. Thus, we conclude that female preference is not always selected in association with a male social trait (social rank) in fish, as predicted by Fisher's Hypothesis (Krebs \& Davies 1993). It is possible that dominance is a way to guarantee "good genes" for brood survival independently of selection of preference for traits in females. This is a speculation, but social fish should give us some new direction to understand ultimate causes in sexual selection, and also evolution of social behaviour. 


\section{REFERENCES}

ALMEIDA, O.G.; MIRANDA, A.; FRADE, P.; HUBBARD, P.C.; BARATA, E.N. \& CANÁRIO, A.V.M. 2005. Urine as a social signal in the Mozambique tilapia (Oreochromis mossambicus). Chemical Senses, 30: 1309-1310.

AMORIM, M.C.P.; KNIGHT, M.E.; STRATOUDAKIS, Y. \& TURNER, G.F. 2004. Differences in sounds made by courting males of three closely related Lake Malawi cichlid species. Journal of Fish Biology, 65: 1358-1371.

AMORIM, M.C.P.; SIMOES, J.M.; FONSECA, P.J. \& TURNER, G.F. 2008. Species differences in courtship acoustic signals among five Lake Malawi cichlid species (Pseudotropheus spp.). Journal of Fish Biology, 72: 1355-1368.

ANDERSSON, M.B. 1994. Sexual Selection. Princeton, NJ: Princeton University Press. 599p.

ANDERSSON, M.B. \& IWASA, Y. 1996. Sexual selection. TREE, 11: 53-58.

ANDERSSON, M. \& SIMMONS, L.W. 2006. Sexual selection and mate choice. Trends in Ecology \& Evolution, 21: 296-302.

AHNESJÖ, I.; FORSGREN, E. \& KVARNEMO, C. 2008. Variation in sexual selection in fishes. Pp. 303-335. In: C. Maghagen, V. Braithwaite, E. Forsgren \& B.G. Kapoor (eds.) Fish Behaviour. Science Publishers, New Hampshire. 648p.

BAIER, B. \& KRAMER, B. 2007. Electric communication during courtship and spawning in two sibling species of dwarf stonebasher from southern Africa, Pollimyrus castelnaui and $P$. marianne (Mormyridae, Teleostei): evidence for a non speciesspecific communication code? Behaviour, 144: 115-142.

BARATA, E.N.; SERRANO, R.M.; MIRANDA, A.; NOGUEIRA, R.; HUBBARD, P.C. \& CANÁRIO, A.V.M. 2008. Putative pheromones from the anal glands of male blennies attract females and enhance male reproductive success. Animal Behaviour, 75: 379-389.

BAKKER, T.C.M. \& MILINSKY, M. 1993. The advantages of being red - sexual selection in the stickleback. Marine Behaviour and Physiology, 23: 287-300.

BARBER, I.; ARNOTT, S.A.; BRAITHWAITE, V.A.; ANDREW, J. \& HUNTINGFORD, F.A. 2001. Indirect fitness consequences of mate choice in sticklebacks: offspring of brighter males grow slowly but resist parasitic infections. Proceedings of the Royal Society of London - Series B: Biological Sciences, 268: 71-76.

BARBOSA, M. \& MAGURRAN, A.E. 2006. Female mating decisions: maximizing fitness? Journal of Fish Biology, 68: $1636-1661$
BARLOW, G.W. 1998. Sexual selection models for exaggerated traits are useful but constraining. American Zoologist, 38: 59-69.

BARLOW, G.W \& LEE, J.S.F. 2005.Sex reversed dominance and aggression in the cichlid fish Julidochromis marlieri. Annales Zoologici Fennici, 42: 477-483.

BERGLUND, A.; BISAZZA, A. \& PILASTRO, A. 1996. Armaments and ornaments: an evolutionary explanation of traits of dual utility. Biological Journal of the Linnean Society, 58: 385-399.

BERGLUND, A. \& ROSENQVIST, G. 2001. Male pipefish prefer dominant over attractive females. Behavioral Ecology, 12: 402-406. BERGLUND, A. \& ROSENQVIST, G. 2003. Sex role reversal in the pipefish. Advances in the Study of Behaviour, 32: 131-167.

BIRKHEAD, T. \& MØLLER, A. 1993. Female control of paternity. Trends in Ecology and Evolution, 8: 100-104.

BISAZZA, A. \& MARIN, G. 1991. Male size and female mate choice in the eastern mosquitofish (Gambusia holbrooki: Poeciliidae). Copeia, 3: 730-735.

BOROWSKY, R.L. 1987. Agonistic behavior and social inhibition of maturation in fishes of the genus Xiphophorus (Poeciliidae). Copeia, 1987: 792-796.

BRUCE, K.E. \& WHITE, W.G. 1995. Agonistic relationships and sexual behaviour patterns in male guppies, Poecilia reticulate. Animal Behaviour, 50: 1009-1021.

CANDOLIN, U. 1999. Male-male competition facilitates female choice in sticklebacks. Proceedings of the Royal Society of London, Series B, 266: 785-789.

CANDOLIN, U. 2000. Male-male competition ensures honest signaling of male parental ability in the three-spined stickleback (Gasterosteus aculeatus). Behavioral Ecology and Sociobiology, 49: 57-61.

CANDOLIN, U. \& WONG, B.B.M. 2008. Mate choice. Pp. 337-376. In: C. Maghagen, V. Braithwaite, E. Forsgren \& B.G. Kapoor (eds.). Fish Behaviour. Science Publishers, New Hampshire. 648p.

CASTRO, A.L.S. 2008. Efeito do contato macho-fêmea na preferência da fêmea e na competição entre machos de tilápiado-Nilo. Tese de Doutorado. CAUNESP, UNESP, Jaboticabal, Brasil. 61p.

CASTRO, A.L.S.; GONÇALVES-DE-FREITAS, E.; VOLPATO, G.L. \& OLIVEIRA, C. 2009 In press. Visual communication stimulates reproduction in Nile tilapia, Oreochromis niloticus (L.). Brazilian Journal of Medical and Biological Research. 
CHARNOV, E.L. 2001. Reproductive efficiencies in the evolution of life histories. Evolutionary Ecology Research, 3: 873-876.

CLEMENT, T.S.; GRENS, K.E. \& FERNALD, R. D. 2004. Female affiliative preference depends on reproductive state in the African cichlid fish. Behavioral Ecology, 16: 83-88.

CLUTTON-BROCK, T. 2007. Sexual selection in males and females. Science, 318: 1882-1885.

COULDRIDGE, V.C.K. \& ALEXANDER, G.J. 2001. Does the time spent near a male predict female mate choice in a Malawian cichlid? Journal of Fish Biology, 59: 667-672.

CUBILLOS, E.R. \& GUDERLEY, H.E. 2000. Analysis of the factors related with mate choice and reproductive success in male in three-spined sticklebacks. Journal of Fish Biology, 56: 1201-1216.

DIJKSTRA, P.D.; VAN DER ZEE, E.M. \& GROOTHUIS, T.G.G. 2008. Territory quality affects female preference in a Lake Victoria cichlid fish. Behavioural Ecology and Sociobiology, 62: 747-755.

DOSEN, L.D. \& MONTGOMERIE, R. 2004. Female size influences mate preferences of male guppies. Ethology, 110: 245-255.

EMLEN, S.T. \& ORING, L.W. 1977. Ecology, sexual selection, and the evolution of the mating systems. Science, 197: 215-223.

FAGUNDES, T.; GONCALVES, D.M. \& OLIVEIRA, R.F. 2007. Female mate choice and mate search tactics in a sex role reversed population of the peacock blenny Salaria pavo (Risso, 1810). Journal of Fish Biology, 71: 77-89.

FISHER, H.S. \& ROSENTHAL, G.G. 2006. Female swordtail fish use chemical cues to select well-fed mates. Animal Behaviour, 72: 721-725.

FORSGREN, E. 1997. Female sand gobies prefer good fathers over dominant males. Proceedings of the Royal Society of London, 264(1386): 1283-1286.

FORSGREN, E.; AMUNDSEN, T.; BORG, A.A. \& BJELVENMARK, J. 2004. Unusually dynamic sex roles in a fish. Nature, 429: 551-554.

GIAQUINTO, P.C. \& VOLPATO, G.L. 1997. Chemical communication, aggression, and conspecific recognition in the fish Nile tilapia. Physiology and Behaviour, 62: 1333-1338.

GIAQUINTO, P.C. \& VOLPATO, G.L. 2005. Chemical cues related to conspecific size in pintado catfish, Pseudoplatystoma coruscans. Acta Ethologica, 8: 65-69.

GODIN, J.J. \& BRIGGS, S.E. 1996. Female mate choice under predation risk in the guppy. Animal Behaviour, 51: 117-130.
GONÇALVES, D.M.; SIMÕES, P.C.; CHUMBINHO, A.C.; CORREIA, M. J.; FAGUNDES, T. \& OLIVEIRA, R. F. 2002a. Fluctuating asymmetries and reproductive success in the peacock blenny. Journal of Fish Biology, 60: 810-820.

GONÇALVES, D.M.; BARATA, E.N.; OLIVEIRA, R.F. \& CANÁRIO, A.V.M. 2002b. The role of male visual and chemical cues on the activation of female courtship behavior in the sex-role reversed peacock blenny. Journal of Fish Biology, 61: 96-105.

GONÇALVES-DE-FREITAS, E. \& NISHIDA, S. M. 1998. Sneaking behaviour of the Nile tilapia. Boletim Técnico do Cepta, 11: 71-79.

GONÇALVES-DE-FREITAS, E.; TERESA, F.B.; GOMES, F.S. \& GIAQUINTO, P.C. 2008. Effect of water renewal on dominance hierarchy of the Nile tilapia. Applied Animal Behaviour Science, 112: 187-195.

GOZLAN, R.E.; FLOWER, C.J. \& PINDER, A.C. 2003. Reproductive success in male sunbleak, a recent invasive fish species in the U.K. Journal of Fish Biology, 63: 131-143.

HALLIDAY, T.R. 1994. Sex and evolution. Pp. 150-192. In: P.J.B. Slater \& T.R. Halliday (eds.). Behaviour and Evolution. Cambridge University Press, Cambridge. 348p.

HANKSON, S.J. \& MORRIS, M.R. 2003. Avoiding a compromisse between sexual selection and species recognition: female Swordtail Fish assess multiple species-specific cues. Behavioral Ecology, 14: 282-287.

HERDMAN, E.J.E.; KELLY, C.D. \& GODIN, J.G.J. 2004. Male mate choice in the guppy (Poecilia reticulata): do males prefer larger females as mates? Ethology, 110: 97-111.

HOFMANN, H.A.; BENSON, M.E. \& FERNALD, R.D. 1999. Social status regulates growth rate: Consequences for life-history strategies. Proceedings of the National Academy of Sciences, 96: 14171-14176.

HOPKINS, C.D. 1974. Electric communication in the reproductive behavior of Sternopygus macrurus (Gymnotoidae). Zeitschrift für Tierpsycologie, 35: 518-535.

HUNTINGFORD, F. \& TURNER, A. 1987. Animal Conflict. Chapman and Hall, New York. 448p.

JORDAN, R.; HOWE, D.; KNIGHT, T. \& GOULD, J. 2006. Female choice linked to male dorsal fin height in a shortfin molly. Journal of Ethology, 24: 301-304.

KANGAS, N. \& LINDSTROM, K. 2001. Male interactions and female mate choice in the sand goby, Pomatoschistus minutes. Animal Behaviour, 61: 425-430. 
KREBS, J.R. \& DAVIES, N.B. 1993. An Introduction to Behavioural Ecology (Third Edition). Oxford: Blackwell Science. $412 p$.

KODRIC-BROWN, A. 1992. Male-dominance can enhance mating success in guppies. Animal Behaviour, 44: 165-167.

KODRIC-BROWN, A. 1993. Female choice of multiple male criteria in guppies - interacting effects of dominance, coloration and courtship. Behavioral Ecology and Sociobiology, 32: 415-420.

KOLM, N. 2001. Females produce larger eggs for large males in a paternal mouthbrooding fish. Proceedings of the Royal Society of London-Series B, 268: 2229-2234.

KRAAK, S.B.M. \& BAKKER, T.C.M. 1998. Mutual mate choice in sticklebacks: attractive males choose big females, which lay big eggs. Animal Behaviour, 56: 859-866.

KRAAK, S.B.M.; BAKKER, T.C.M. \& MUNDWILER, B. 1999. Sexual selection in sticklebacks in the field: correlates of reproductive, mating, and paternal success. Behavioral Ecology, 10: 696-706.

KÜNZLER, R. \& BAKKER, T.C.M. 2001. Female preferences for single and combined traits in computer animated stickleback males. Behavioral Ecology, 12: 681-685.

KVARNEMO, C. \& AHNESJÖ, I. 1996. The dynamics of operational sex ratios and competition for mates. Trends in Ecology and Evolution, 17: 144-148.

LABONNE, J.; AUGERY, M.; PARADE, M.; BRINKERT, S.; PREVOST, E.; HE' LAND, M. \& BEALL, E. 2009. Female preference for male body size in brown trout, Salmo trutta: is big still fashionable? Animal Behaviour, 77: 129-137.

LAILVAUX, S.P. \& IRSCHICK, D.J. 2006. A functional perspective on sexual selection: insights and future prospects. Animal Behaviour, 72: 263-273.

LOCATELLO, L.; RASOTTO, M.B.; EVANS, J.P. \& PILASTRO, A. 2006. Colourful male guppies produce faster and more viable sperm. Journal of Evolutionary Biology, 19: 15951602.

MACHNIK, P. \& KRAMER, B. 2008. Journal of Experimental Biology, 211: 1969-1977.

MCKAYE, K.-R.; LOUDA, S.-M. \& STAUFFER, J.-R. 1990. Bower size and male reproductive success in a cichlid fish lek. The American Naturalist, 135: 597-613.

MCLENNAN, D.A. \& RYAN, M.J. 2008. Female swordtails, Xiphophorus continens, prefer the scent of heterospecific males. Animal Behaviour, 75: 1731-1737.
MENDONÇA, F.Z. \& GONÇALVES-DE-FREITAS, E. 2008. Nest deprivation and mating success in Nile tilapia (Teleostei: Cichlidae). Revista Brasileira de Zoologia, 25: 413-418.

MORRIS, M.R.; TUDOR, M.S. \& DUBOIS, N. S. 2007. Sexually selected signal attracted females before deterring aggression in rival males. Animal Behaviour, 74: 1189-1197.

NELSON, C.M. 1995. Male size, spawning pit size and female mate choice in a lekking cichlid fish. Animal Behaviour, 50: 1587-1599.

NICOLETTO, P.F. 1993. Female sexual-response to conditiondependent ornaments in the guppy, Poecilia reticulata. Animal Behaviour, 46: 441-450.

ÖSTLUND, S. \& AHNESJÖ, I. 1998. Female fifteen-spined sticklebacks prefer better fathers. Animal Behaviour, 56: 11771183.

ÖSTLUND-NILSSON, S. \& HOLMLUND, M. 2003. The artistic three-spined stickleback (Gasterosteus aculeatus). Behavioral Ecology and Sociobiology, 53: 214-220.

ÖSTLUND-NILSSON, S. \& NILSSON, G.E. 2000. Free choice by female sticklebacks : lack of preference for male dominance traits. Canadian Journal of Zoology, 78: 1251-1258.

PETERSSON, E.; JÄRVI, T.; OLSÉN, H.; MAYER, I. \& HEDENSKOG, M. 1999. Male-male competition and female choice in brown trout. Animal Behaviour, 57: 777-783.

PHILLIPS, C.T. \& JOHNSTON, C.E. 2008. Sound production and associated behaviors in Cyprinella galactura. Environmental Biology of Fishes, 82: 265-275.

QVARNSTRÖM A. \& FORSGREN, E. 1998. Should females prefer dominant males? TREE vol. 13(12): 498-501.

REICHARD,M.;BRYJA,J.;ONDRACKOVÁ,M.;DÁVIDOVÁ, M.; KANIEWWSKA, P. \& SMITH, C. 2005. Sexual selection for male dominance reduces opportunities for female mate choice in the European bitterling (Rhodeus sericeus). Molecular Ecology, 14: 1533-1542.

RIDLEY, M. 1995. Animal Behavior. Blackwell Scientific Publications, Boston. 288p.

ROSENTHAL, G.G. \& LOBEL, P.S. 2006. Communication. Pp. 39-78. In: K.A. Sloman, R.W. Wilson \& S. Balshine (eds.). Behaviour and Physiology of Fish (Fish Physiology series, v. 24). Elsevier Academic Press, London. 480p.

SANTANGELO, N. 2005. Courtship in the monogamous convict cichlid; what are individuals saying to rejected and selected mates? Animal Behaviour, 69: 143-149. 
SARGENT, R.C.; RUSH, V.N. WISENDEN, B.D. \& YAN, H.Y. 1998. Courtship and mate choice in fishes: integrating behavioral and sensory ecology. American Zoologist, 38: 82-96.

SCHARTL, M.; ERBELDINGDENK, C.; HOLTER, S.; NANDA, I.; SCHMID, M.; SCHRODER, J.H. \& EPPLEN, J.T. 1993. Reproductive failure of dominant males in the poeciliid fish Limia perugiae determined by DNA-fingerprinting. Proceedings of the National Academy of Sciences o the United States of America, 90: 7064-7068.

SHIBATA, J. \& KODA, M. 2006. Seasonal sex role changesin the bleniidae Petroscirtes breviceps, a nest brooder with paternal care. Journal of Fish Biology, 69: 203-214.

SERRANO, R.M.; BARATA, E.N.; BIRKETT, M.A.; HUBBARD, P.C.; GUERREIRO, P.S. \& CANARIO, A.V.M. 2008. Behavioral and olfactory responses of female Salaria pavo (Pisces: Blenniidae) to a Putative Multi-component Male Pheromone. Journal of Chemical Ecology, 34: 647-658.

STAUFFER, J-R.; KELLOGG, K.-A. \& MCKAYE, K.-R. 2005. Experimental evidence of female choice in lake Malawi cichlids. Copeia, 2005: 657-660.

TAKAHASHI, D. \& KOHDA, M. 2004. Courtship in fast water currents a male stream goby (Rhinogobius brunneus) communicates the parental quality honestly. Behavioral Ecology and Sociobiology, 55: 431-438.

TERLEPH, T.A. \& MOLLER, P. 2003. Effects of social interaction on the electric organ discharge in a mormyrid fish, Gnathonemus petersii (Mormyridae, Teleostei). Journal of Experimental Biology, 206: 2355-2362.

TRAINOR, B.C. \& BASOLO, A. 2006. Location, location, location: stripe position effects on female sword preference. Animal Behaviour, 71: 135-140.

TRIEFENBACH, F. \& ZAKON, H. 2003. Effects of sex, sensitivity and status on cue recognition in the weakly electric fish Apteronotus leptorhynchus. Animal Behaviour, 65: 19-28.

VOLPATO, G.L. \& FERNANDES, M.O. 1994. Social control of growth in fishes. Brazilian Journal of Medical and Biological Research, 27: 797-810.

VOLPATO, G.L.; CASTRO, A.L.S.; GONÇALVES-DEFREITAS, E.; GIAQUINTO, P.C.; FERNANDES-CASTILHO, M.; PEREIRA-DA-SILVA, E.M. \& JORDÃO, J.C. 2006. Comunicação Química em Peixes. Pp. 17-51. In: J.E.P. Cyrino \& E.C. Urbinati (Eds.). Tópicos Especiais em Biologia Aquática e Aqüicultura. Sociedade Brasileira de Aqüicultura e Biologia Aquática. 293p.
WEATHERHEAD, P.J. \& ROBERTSON, R.J. 1979. Offspring quality and the polygyny threshold-sexy son hypothesis. American Naturalist, 113: 201-208.

WERNER, N.Y. \& LOTEM, A. 2003. Choosy males in haplochromine cichlid: first experimental evidence for male mate choice in a lekking species. Animal Behaviour, 66: 293-298.

WONG, B.B.M. 2004. Superior fighters make mediocre fathers in the Pacific blue-eye fish. Animal Behaviour, 67: 583-590.

WONG, R.Y. \& HOPKINS, C.D. 2007. Electrical and behavioral courtship displays in the mormyrid fish Brienomyrus brachyistius. Journal of Experimental Biology, 13: 2244-2252.

Submetido em 13/11/2008. Aceito em 06/12/2008. 